\title{
Author Correction: A brain-wide functional map of the serotonergic responses to acute stress and fluoxetine
}

\author{
Joanes Grandjean (D), Alberto Corcoba, Martin C. Kahn (D, A. Louise Upton, Evan S. Deneris, Erich Seifritz, \\ Fritjof Helmchen, Isabelle M. Mansuy, Edward O. Mann (1), Markus Rudin \& Bechara J. Saab
}

Correction to: Nature Communications https://doi.org/10.1038/s41467-018-08256-w, published online 21 January 2019.

The original version of this Article omitted from the author list the 8th author Isabelle M. Mansuy who is from the 'Laboratory of Neuroepigenetics, Brain Research Institute, Medical Faculty of the University of Zürich, Institute for Neuroscience, Department of Health Science and Technology of ETH Zürich, Irchel Campus Room Y55H66, Winterthurerstrasse 190, CH-8057, Zürich, Switzerland'.

Consequently, the following was added to the Acknowledgements: 'and funding from University Zürich, ETH Zürich and the Swiss National Science Foundation (grant 31003A-135715) awarded to I.M.M.' The following text was added to the "Methods" section 'ZH150/11 given to I.M.M. and '. The following text was added to the Author Contributions: 'B.J.S. and A.C. performed some experiments reported in this article while supervised by I.M.M'. This has been corrected in both the PDF and HTML versions of the Article.

B.J.S. disagrees with the addition of Isabelle Mansuy as an author.

Published online: 15 February 2021

\footnotetext{
(c) Open Access This article is licensed under a Creative Commons Attribution 4.0 International License, which permits use, sharing, adaptation, distribution and reproduction in any medium or format, as long as you give appropriate credit to the original author(s) and the source, provide a link to the Creative Commons license, and indicate if changes were made. The images or other third party material in this article are included in the article's Creative Commons license, unless indicated otherwise in a credit line to the material. If material is not included in the article's Creative Commons license and your intended use is not permitted by statutory regulation or exceeds the permitted use, you will need to obtain permission directly from the copyright holder. To view a copy of this license, visit http://creativecommons.org/licenses/by/4.0/.
}

(C) The Author(s) 2021 